\title{
UPAYA MENINGKATKAN KUALITAS PEMBELAJARAN SEJARAH INDONESIA KELAS XI IIS 1 MELALUI PENERAPAN OUTDOOR LEARNING BERBASIS INKUIRI DI SMAN KUNIR TAHUN AJARAN 2015-2016
}

\author{
Zainul Hasan \\ SMA Sabillilah Malang
}

\begin{abstract}
Abstrak: Penelitian ini berfokus pada penyelesaian masalah kualitas pembelajaran sejarah Indonesia di kelas XI IIS 1 SMAN Kunir. Permasalahan kualitas pembelajaran di kelas ini mencakup rendahnya proses pembelajaran dalam hal keaktifan dan hasil belajar siswa. Upaya yang dilakukan untuk meningkatkan kualitas pembelajaran dilakukan dengan menerapkan outdoor learning berbasis inkuiri. Hasil penelitian menunjukkan adanya peningkatan kualitas pembelajaran setelah dua kali siklus pemberian tindakan.
\end{abstract}

Kata-kata kunci: keaktifan, hasil belajar, outdoor learning, inkuiri

Abstract: this study focuses on the problem solving of the quality of teaching and learning of Indonesian history in the class of XI IIS 1 SMAN Kunir. The problem is the passiveness and the grade of students during and after the teaching process. An effort was done by improving the quality of teaching through the outdoor learning based on inquiry. This study found a significant increase after two cycles of giving action.

Keywords: activeness, learning grade, outdoor learning, inquiry

Pembelajaran sejarah pada jenjang Sekolah Menengah Atas (SMA) memerlukan sebuah inovasi dalam pemberian tindakan untuk mengatasi permasalahan yang terjadi di dalam kelas. Contoh permasalahan yang dihadapi seperti sumber belajar, model, metode, siswa, dan kemampuan guru dalam menyampaikan materi kepada siswa. Permasalahan-permasalahan tersebut juga terjadi di SMAN Kunir yang terletak di Kecamatan Kunir, Kabupaten Lumajang. Sejarah merupakan salah satu matapelajaran yang dalam kegiatan pembelajarannya terdapat permasalahan. Di SMAN Kunir terdapat beberapa guru pengajar matapelajaran sejarah, yakni Pak Wawan Cahyono, Ibu Sri Ratnasari dan Ibu Radna Dwi Astuti. Alasan mengapa di sekolah ini terdapat tiga guru pengajar karena jam pelajaran yang cukup banyak sesuai dengan Kurikulum 2013.

Pada observasi awal, peneliti mendapatkan informasi bahwa terdapat salah satu kelas yang bermasalah dalam proses dan hasil belajar, yakni XI IIS 1. Pembelajaran sejarah di kelas XI IIS 1 memerlukan sebuah tindakan khusus untuk menyelesaikan masalah yang dihadapi siswa.
Permasalahan yang dihadapi adalah proses dan hasil belajar yang kurang maksimal jika dibandingkan dengan kelas lainnya.

Siswa di kelas XI IIS 1 terlihat jenuh dan cenderung sulit megikuti pembelajaran yang dilakukan. Kejenuhan siswa dalam mengikuti pembelajaran terjadi karena proses pembelajaran yang secara umum lebih banyak dilaksanakan di dalam kelas saja. Akibat dari kejenuhan siswa ini adalah pengaruh pada aktivitas siswa di kelas yang cenderung kurang aktif. Siswa kurang aktif dalam bertanya, menjawab/pemecahan masalah, mengumpulkan informasi dan diskusi.

Di awal pembelajaran terdapat siswa yang berada di luar kelas dengan aktivitas yang tidak berkaitan dengan pembelajaran. Seharusnya siswa sudah berada di dalam kelas dan siap mengikuti pembelajaran. Kesiapan diperlukan agar mampu melaksanakan kegiatan (belajar) dengan baik dimana kesiapan tersebut kesiapan fisik, psikis, dan kematangan dalam melakukan sesuatu yang dipengaruhi oleh pengalaman (Suyono \& Hariyanto, 2011: 126).

Guru pengajar meminta ketua kelas untuk memanggil siswa yang masih berada di luar kelas 
agar segera masuk dan mengikuti pembelajaran. Setelah semua siswa berada di dalam kelas, guru melaksanakan pembelajaran seperti biasa dengan mengucapkan salam, menyampaikan tujuan dan kompetensi dasar yang hendak dicapai. Ketika guru menyampaikan gambaran umum materi, siswa mulai terlihat kurang fokus.

Terdapat beberapa siswa yang berbicara dengan teman sebangku ataupun di depannya. Aktivitas siswa ini berjalan dengan waktu yang cukup lama sehingga mengganggu pembelajaran. Guru memberikan peringatan halus untuk berhenti melakukan kegiatan di luar konteks pembelajaran sejarah, tetapi peringatan halus yang diberikan tidak memberikan efek jera pada siswa.

Masalah lain ialah ketika terdapat siswa berinisial AR tidur saat guru menyampaikan materi pembelajaran. Guru menghampiri AR dan menyuruhnya untuk membasuh muka agar tidak mengantuk lagi ketika di kelas. Keadaan ini membuat kelas menjadi gaduh karena beberapa siswa mengejek AR yang tertidur di kelas.

Setelah guru pengajar menyampaikan gambaran umum materi, beliau menyuruh siswa untuk membentuk kelompok diskusi. Instruksi dari guru terlihat kurang diperhatikan oleh siswa karena diskusi tidak berjalan dengan baik. Hal ini terjadi karena terdapat beberapa siswa yang tidak mau berdiskusi. Hal ini berkaitan dengan keaktifan siswa dalam berdiskusi, bertanya, menjawab dan mengumpulkan informasi. Peneliti juga melihat bahwa keaktifan siswa selain berdiskusi juga rendah, misalnya ketika guru memberikan pertanyaan.

Peneliti berasumsi bahwa ketika sebuah proses pembelajaran kurang maksimal, maka hasil belajar siswa juga akan kurang maksimal. Di SMAN Kunir telah ditentukan Kriteria Ketuntasan Minimal (KKM) untuk matapelajaran sejarah Indonesia adalah 75. Rata-rata nilai tugas siswa kelas XI II 1 hanya 76,1 dan nilai ulangan harian pertama 73,55. Pada ulangan-ulangan selanjutnya siswa juga mengalami kendala pada hasil belajarnya. Hasil belajar pada Ulangan Akhir Semester Ganjil juga menunjukkan hasil yang kurang maksimal dengan rata-rata 69.

Rendahnya proses belajar (keaktifan) dan hasil belajar di kelas XI IIS 1 menunjukkan bahwa kualitas pembelajaran masih cukup rendah. Pembelajaran merupakan hubungan timbal balik antara tujuan, metode, materi dan evaluasi, serta menciptakan kondisi yang kondusif agar terjadi komunikasi belajar mengajar (Rusman, dkk, 2012: 15). Pada pernyataan ini jelas terlihat bahwa pembelajaran bukan hanya menyampaikan informasi kepada siswa, tetapi juga terdapat hal-hal yang menjadi kaidah yang harus ditaati. Tujuan pembelajaran secara mutlak harus dijelaskan dan ditentukan sebelum melaksanakan pembelajaran.

Hamalik (dalam Sanjaya, 2011: 6) menjelaskan bahwa sistem pembelajaran merupakan kombinasi unsur manusiawai, material, fasilitas, perlengkapan dan prosedur yang berinteraksi untuk mencapai suatu tujuan. Pendapat ini jauh lebih kompleks lagi menjelaskan faktor-faktor yang dapat mempengaruhi pembelajaran. Jika sebelumnya Rusman, dkk. (2012) lebih mengacu pada tujuan, metode, dan evaluasi, Hamalik (dalam Sanjaya, 2011) juga menekankan adanya pengaruh hal-hal di luar kelas terhadap kualitas pembelajaran.

Berdasarkan permasalahan di atas, peneliti berupaya memberikan solusi pemecahan masalah untuk meningkatkan kualitas pembelajaran di kelas XI IIS 1. Solusi yang diberikan oleh peneliti adalah pemberian tindakan berupa penerapan outdoor learning berbasis inkuiri. Alasan penerapan model adalah kesesuaian dengan permasalahan yang terjadi di kelas XI IIS 1 . Peneliti melihat bahwa pelru adanya model yang dapat membuat siswa merasa senang dan tidak jenuh mengikuti pembelajaran, tetapi masih tetap terjadi pembelajaran yang baik.

Outdoor learning di Indonesia banyak disebut dengan istilah outdoor study dimaknai bukan hanya belajar atau berdiskusi di luar ruangan, tetapi lebih pada aplikasi terhadap kehidupan sehari-hari (Marfuah, dkk, 2014: 659-660). Hal ini berkaitan erat dengan amanat yang terdapat pada Kurikulum 2013, yakni siswa harus memiliki keterampilan. Keterampilan yang dimaksud dalam Kurikulum 2013 mencakup banyak hal mulai dari pengetahuan, sikap dan praktik di lapangan. 
Langkah-langkah pembelajaran outdoor learning mencakup persiapan kelas, penentuan tempat, dinamika kelompok, mengelola peralatan di lapangan, bekerja di lapangan, dan kembali ke kelas membuat laporan akhir (Sumarmi, 2012: 91-92). Pendapat Sumarmi menunjukkan bahwa pembelajaran yang dilakukan memerlukan latar berupa situs sejarah. Pertimbangan materi dan izin kepala sekolah membuat peneliti memodifikasi langkah-langkah pembelajaran tersebut sesuai dengan outdoor learning yang tidak memerlukan latar situs sejarah.

Indramunawar (dalam Nurhasanah, dkk., 2013: 4) menyimpulkan pengertian outdoor learning sebagai berikut.

Outdoor education activities adalah kegiatan di alam bebas atau kegiatan di luar kelas dan mempunyai sifat menyenangkan, karena bisa melihat, menikmati, mengagumi dan belajar mengenai ciptaan Tuhan Yang Maha Kuasa yang terbentang di alam, yang dapat disajikan dalam bentuk permainan, observasi atau pengamatan, simulasi, diskusi, dan petualangan sebagai media penyampaian materi.

Outdoor learning jelas tidak menuntut adanya sebuah pembelajaran yang harus ke situs sejarah sehingga pembelajaran luar ruangan yang dilaksanakan tidak bersifat kaku. Berdasarkan pengertian outdoor learning di atas, peneliti bekerja sama dengan guru pengajar untuk merancang sebuah pembelajaran yang sesuai dengan lingkungan sekolah dan materi pembelajaran. Peneliti dan guru merancang pembelajaran sejarah Indonesia yang berlatar outdoor learning dan memasukkan unsur model inkuiri untuk meningkatkan kualitas pembelajaran.

Inkuiri (inquiry) berasal dari kata "to inquire" yang berarti ikut serta atau terlibat, dalam mengajukan pertanyaan-pertanyaan, mencari informasi, dan mengajukan penyelidikan (Suryani \& Agung, 2012: 119). Model ini menginginkan sebuah kegiatan pembelajaran yang bersifat ilmiah dengan berpikir kritis untuk memecahkan masalah. Pembelajaran inquiry adalah rangkaian kegiatan pembelajaran yang menekankan pada proses berpikir secara kritis dan analisis untuk mencari dan menemukan sendiri jawaban dari suatu masalah yang dipertanyakan (Sanjaya, 2006:194).

Inquiry learning emphasizes active learning and development of analytical skills as opposed to rote memorization (Bruner dalam Moos dan Honkomp, 2011: 234). Pendapat Bruner ini menjelaskan bahwa inkuiri seharusnya menekankan pembelajaran yang bersifat ilmiah sehingga membuat siswa mampu bersikap aktif dan melakukan analisis. Permasalahan yang banyak di lapangan penggunaan inkuiri lebih pada pengetahuan saja.

Peneliti memilih inkuiri terbimbing untuk dipadukan dengan outdoor learning karena langkah-langkah pembelajarannya yang cukup mudah diikuti oleh siswa XI IIS 1 dan sesuai dengan permasalahan yang dihadapi di lapangan. Langkah-langkah inkuiri terbimbing pada penelitian ini adalah orientasi, merumuskan masalah, merumuskan hipotesis, mengumpulkan data, menguji hipotesis, dan merumuskan kesimpulan (Sanjaya, 2011:202-205).

\section{METODE}

Penelitian ini dilaksanakan di kelas XI IIS 1, SMAN Kunir, Kabupaten Lumajang pada tahun ajaran 2015-2016. Penelitian ini dilaksanakan dalam dua siklus, tiap siklus terdiri dari beberapa tahapan yakni perencanaan, tindakan, observasi, refleksi, dan rencana perbaikan. Siklus I dilaksanakan dalam dua kali pertemuan dengan materi Sekitar Proklamasi: Dari Rengasdengklok hingga Pegangsaan Timur. Siklus II dilaksanakan dalam tiga kali pertemuan dengan materi Pembentukan Negara Kesatuan Republik Indonesia (NKRI). Subjek dari penelitian ini adalah siswa kelas XI IIS 1, dengan jumlah siswa 28. Teknik pengumpulan data yang digunakan meliputi dokumentasi, observasi, wawancara, dan tes.

Penelitian ini berupaya meningkatkan kualitas pembelajaran yang difokuskan pada proses pembelajaran (keaktifan) dan hasil belajar. Indikator keaktifan pada penelitian ini mengadopsi dari pendapat Sudjana (2011: 61) 
dengan beberapa penyesuaian yang menghasilkan empat indikator keaktifan mencakup mengumpulkan informasi, bertanya, menjawab/pemecahan masalah, dan diskusi. Penilian terhadap hasil belajar dilakukan dengan tes formatif yang dilaksanakan pada akhir siklus. Tujuan penilaian formatif ialah untuk memperbaiki dan menyempurnakan proses pembelajaran agar hasil belajar siswa menjadi baik (Arifin, 2013: 35).

\section{HASIL DAN PEMBAHASAN}

Keaktifan Siswa Kelas XI IIS 1 dalam Mengikuti Pembelajaran Sejarah Indonesia Melalui Penerapan Outdoor Learning Berbasis Inkuiri

Keaktifan siswa mengalami peningkatan dari pra siklus hingga siklus II (lihat diagram 1.1). Pada kegiatan pra siklus persentase keaktifan siswa dalam mengumpulkan informasi sebanyak $65.5 \%$, bertanya $57 \%$, menjawab/pemecahan masalah 50.8\%, dan diskusi $65.5 \%$. Pada siklus I persentase keaktifan siswa dalam mengumpulkan informasi sebanyak $78.4 \%$, bertanya $66.3 \%$, menjawab/pemecahan masalah $56.7 \%$, dan diskusi $75 \%$. Pada siklus II persentase keaktifan siswa dalam mengumpulkan informasi sebanyak $81.2 \%$, bertanya $71.5 \%$, menjawab/pemecahan masalah $72.4 \%$, dan diskusi $87 \%$. Persentase keaktifan siswa secara klasikal, meningkat dari $34 \%$ pada pra siklus, menjadi $65 \%$ pada siklus I dan $89 \%$ pada siklus II. Peningkatan keaktifan siswa terjadi karena suasana pembelajaran yang menyenangkan. Siswa juga terlibat aktif dalam kegiatan pembelajaran dengan penerapan outdoor learning berbasis inkuiri.

Kegiatan pembelajaran pada siklus II menjadi lebih menyenangkan karena didesain seperti sebuah permainan yang berada di lingkungan sekolah dengan menggunakan running woods yang berasal dari modifikasi running dictation. Running dictation merupakan metode pembelajaran yang melibatkan siswa secara aktif dalam mencari informasi materi pelajaran dengan cara berlari kemudian mendiktekannya kepada anggota kelompoknya (Wati, 2013: 18). Siswa menjadi lebih senang dalam mengikuti pembelajaran dibandingkan dengan pra siklus dan siklus I. Bukan hanya rasa senang yang diutamakan oleh peneliti, tetapi sikap aktif siswa dalam mengikuti pembelajaran. Hal ini terbukti bahwa keaktifan siswa semakin meningkat karena suasana belajar yang semakin baik dan siswa semakin aktif karena running woods yang menyenangkan juga merupakan bagian dari inkuiri.

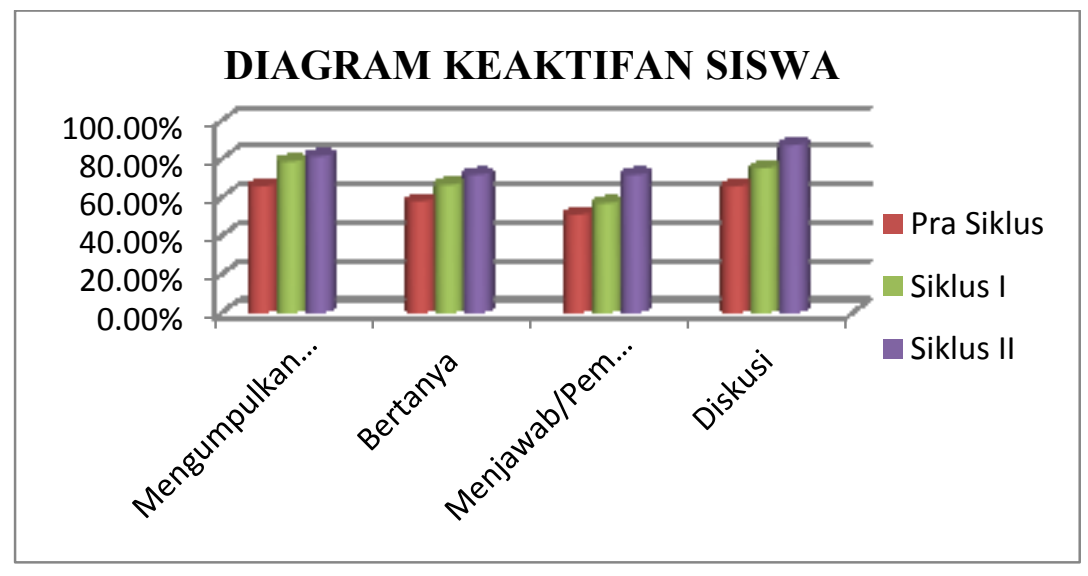

Gambar1.1 Keaktifan Siswa (Sumber: Dokumentasi Peneliti)

Terjadinya peningkatan keaktifan siswa dalam mengikuti pembelajaran sesuai dengan pendapat para ahli yang yang mendukung teori konstruktivistik. Piaget (dalam Suprihatiningrum, 2014) menyatakan sebuah hal penting yang yang perlu dilakukan oleh siswa dalam belajar adalah modifikasi. Makna modifikasi dapat dikatakan sebagai respon yang harus ditampilkan oleh siswa. Kegiatan 
pembelajaran baik pada siklus I maupun siklus II sebenarnya didesain untuk pembelajaran yang menyenangkan dan santai mealui outdoor learning (Indramunawar dalam Nurhasanah, dkk, 2013), tetapi juga dipadukan dengan inkuiri termbimbing (Sanjaya, 2011) yang menuntut siswa aktif mencari dan mengumpulkan informasi untuk menyelesaikan permasalahan. Hal ini bertujuan untuk memancing siswa dalam memodifikasi stimulus yang diberikan oleh guru pengajar. Upaya ini terlihat cukup berhasil ketika diterapkan di kelas XI IIS 1 untuk menyelesaikan permasalahan keaktifan yang dihadapi.

Hasil Belajar Siswa Kelas XI IIS 1 dalam Mengikuti Pembelajaran Sejarah

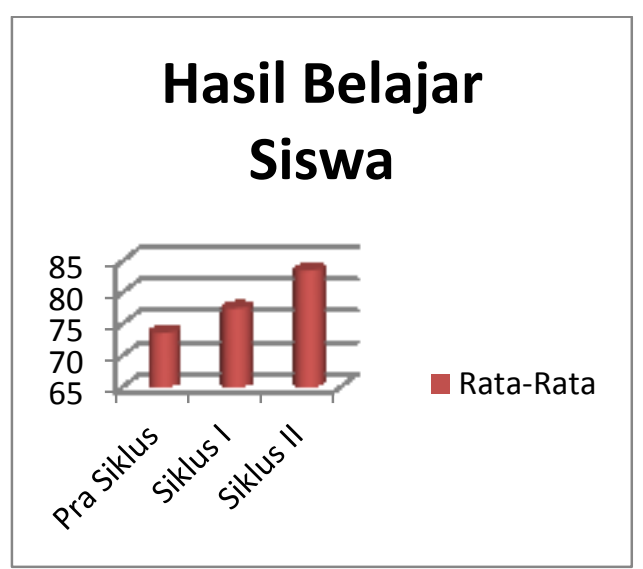

\section{Gambar 2 Rata-rata Hasil Belajar Siswa (Sumber: Dokumentasi Peneliti)}

Peningkatan hasil belajar siswa XI IIS 1 menunjukkan sebuah perubahan yang sangat signifikan. Hal ini menunjukkan bahwa penerapan outdoor learning berbasis inkuiri berhasil. Penerapan model ini dapat digunakan sebagai acuan bagi
Indonesia Melalui Penerapan Outdoor Learning Berbasis Inkuiri

Hasil belajar siswa juga mengalami peningkatan dari pra siklus hingga siklus II (lihat diagram 1.2 dan 1.3). Pada pra siklus rata-rata hasil belajar yang diperoleh siswa XI IIS 1 adalah 73.5 dan persentase ketuntasan klasikal yang diperoleh adalah $75.8 \%$. Pada siklus I mengalami peningkatan rata-rata nilai hasil belajar menjadi 77.4 dan persentase ketuntasan klasikal menjadi 79.3\%. Pada siklus II ratarata nilai hasil belajar 83.4 persentase ketuntasan klasikal hasil belajar siswa, yakni $86.2 \%$. Peningkatan hasil belajar ini tidak lepas dari proses pembelajaran yang semakin baik sehingga memberikan dampak positif terhadap hasil belajar siswa. Hal ini karena proses dan hasil belajar memiliki hubungan yang erat.

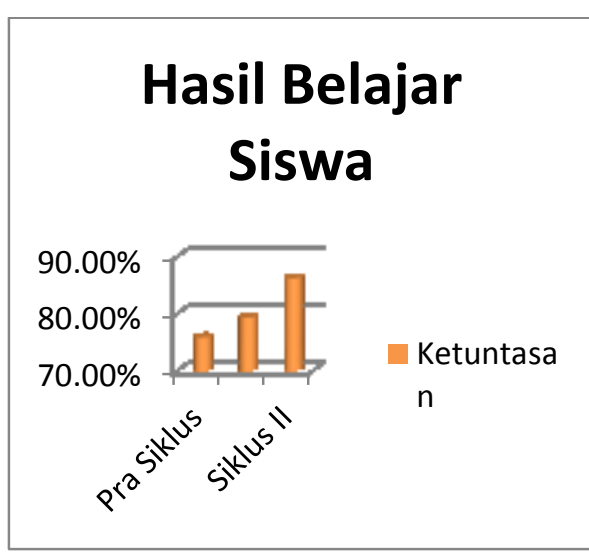

Gambar 3 Ketuntasan Klasikal (Sumber: Dokumentasi Peneliti)

guru jika mengalami masalah hasil belajar siswa yang rendah karena jenuh di dalam kelas. Hasil penelitian menunjukkan adanya peningkatan keaktifan (proses pembelajaran) dan hasil belajar mengindikasikan bahwa kualitas 
pembelajaran sejarah Indonesia di kelas XI IIS 1 meningkat menjadi semakin baik.

\section{PENUTUP}

Berdasarkan hasil penelitian di atas menunjukkan bahwa keaktifan dan hasil belajar siswa mengalami peningkatan dari pra siklus hingga siklus II. Proses (keaktifan) dan hasil belajar yang baik ini menunjukkan bahwa kualitas pembelajaran sejarah Indonesia di kelas XI IIS 1 meningkat. Peningkatan yang terjadi menunjukkan sebuah peningkatan yang cukup baik, bahkan setelah siklus I sudah menunjukkan adanya sebuah peningkatan. Meningkatnya kualitas pembelajaran di kelas XI IIS 1 menunjukkan bahwa penerapan outdoor learning berbasis inkuiri berhasil menyelesaikan masalah yang dihadapi. Berdasarkan kesimpulan di atas saran yang dirumuskan adalah sebagai berikut. Kepala SMAN Kunir hendaknya memberikan himbauan kepada guru masing-masing matapelajaran untuk menciptakan pembelajaran yang menyenangkan. Guru pengajar sejarah Indonesia hendaknya terus berinovasi untuk menciptakan pembelajaran yang menyenangkan bagi siswa. Siswa hendaknya terus belajar, memperhatikan guru, dan bersikap aktif selama mengikuti pembelajaran. Peneliti selanjutnya dapat meneliti penerapan outdoor learning berbasis inkuiri dengan jenis pendekatan yang lain.

\section{DAFTAR RUJUKAN}

Arifin, Z. 2013. Evaluasi Pembelajaran; Prinsip, Teknik, Prosedur. Bandung: PT Remaja Rosdakarya.

Marfuah, I., Mardiyana. \& Kusmayadi, T.A. 2014. Pengembangan Model Pembelajaran NHT
(Number Head Together)

Berbasis Outdoor Study

Untuk Meningkatkan

Prestasi Belajar Siswa Kelas

X Pada Materi Pokok Sistem

Persamaan dan

Pertidaksamaan. Jurnal

Elektronik Pembelajaran

Matematika. Vol 2 (6): 655-

666.

Moos, D.C. \& Honkomp, B. 2011.

Adventure Learning:

Motivating Students in a

Minnesota Middle School.

Journal of Research on

Technology in Education.

Vol. 43 (3): 231-254.

Nurhasanah, M., Rudiyanto, \& Budiana, D. 2013. Pengaruh Permainan Outdoor Education Terhadap Keterampilan Motorik Kasar Anak Taman Kanak-Kanak, (Online),

(www.antologipaud.com), diakses tanggal 29 Oktober 2014.

Purbawati, I.A.G.R., Meter, Gd. \& Wiyasa, I.K.N. 2014. Pengaruh Pendekatan Contextual Teaching and Learning by Outdoor Study Terhadap Hasil Belajar Matematika Siswa Kelas V SD Gugus 4 Samplangan. E-Journal Mimbar PGSD Universitas Pendidikan Ganesha. Vol 2 (1). Online). (Portalgaruda.go.id) diakses tanggal 21 Oktober 2015.

Rusman., Kurniawan, D., \& Riyana, C. 2012. Pembelajaran Berbasis Teknologi Informasi dan Komunikasi; Mengembangkan 
Profesionalitas Guru. Jakarta:

Rajawali Press.

Sanjaya, W. 2006. Strategi Pembelajaran Berorientasi Standar Proses Pendidikan. Jakarta: Kencana Perdana Media Group.

Sanjaya, W. 2011. Perencanaan dan Desain Sistem Pembelajaran. Jakarta: Kecana Prenada Media Grup.

Sudjana, N. 2011. Penilaian Hasil Proses Belajar Mengajar. Bandung: PT Remaja Rosdakarya.

Sumarmi. 2012. Model-model Pembelajaran Geografi. Malang: Aditya Media Publishing.

Suprihatiningrum, J. 2014. Strategi Pembelajaran; Teori dan Aplikasi. Jogjakarta: ArRuzz Media.
Suryani, N. \& Agung, L. 2012. Strategi Belajar Mengajar. Yogyakarta: Ombak.

Suyono \& Hariyanto. 2011. Belajar Pembelajaran; Teori dan Konsep Dasar. Bandung: PT Remaja Rosdakarya Offset.

Wati. 2013. Efektifitas Pendekatan Content and Language Integrated Learning (CLIL) Melalui Running Dictation untuk Meningkatkan Hasil Belajar dan Keterampilan Berkomunikasi Lisan Sekolah Bilingual. Skripsi tidak diterbitkan. Semarang: FMIPA Universitas Negeri Semarang. (Online). (unnes.ac.id), diakses tanggal 28 April 2016 